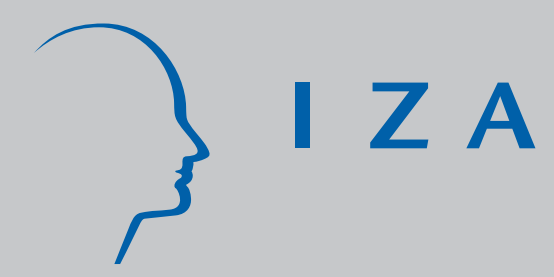

IZA DP No. 842

\title{
Rent Control and Unemployment Duration
}

\author{
Michael Svarer \\ Michael Rosholm \\ J akob Roland Munch
}

August 2003 


\title{
Rent Control and Unemployment Duration
}

\author{
Michael Svarer \\ University of Aarhus \\ Michael Rosholm \\ University of Aarhus and IZA Bonn \\ Jakob Roland Munch \\ Danish Economic Council
}

Discussion Paper No. 842

August 2003

\author{
IZA \\ P.O. Box 7240 \\ D-53072 Bonn \\ Germany \\ Tel.: +49-228-3894-0 \\ Fax: +49-228-3894-210 \\ Email: iza@iza.org
}

This Discussion Paper is issued within the framework of IZA's research area Welfare State and Labor Market. Any opinions expressed here are those of the author(s) and not those of the institute. Research disseminated by IZA may include views on policy, but the institute itself takes no institutional policy positions.

The Institute for the Study of Labor (IZA) in Bonn is a local and virtual international research center and a place of communication between science, politics and business. IZA is an independent, nonprofit limited liability company (Gesellschaft mit beschränkter Haftung) supported by Deutsche Post World Net. The center is associated with the University of Bonn and offers a stimulating research environment through its research networks, research support, and visitors and doctoral programs. IZA engages in (i) original and internationally competitive research in all fields of labor economics, (ii) development of policy concepts, and (iii) dissemination of research results and concepts to the interested public. The current research program deals with (1) mobility and flexibility of labor, (2) internationalization of labor markets, (3) welfare state and labor market, (4) labor markets in transition countries, (5) the future of labor, (6) evaluation of labor market policies and projects and (7) general labor economics.

IZA Discussion Papers often represent preliminary work and are circulated to encourage discussion. Citation of such a paper should account for its provisional character. A revised version may be available on the IZA website (www.iza.org) or directly from the author. 
IZA Discussion Paper No. 842

August 2003

\section{ABSTRACT}

\section{Rent Control and Unemployment Duration*}

In this paper we investigate whether rent control affects the functioning of the labour market. Particularly, we focus on the effect of rent control on the length of individual unemployment duration. Theoretically, the effect is ambiguous. Rent control reduces housing mobility and could very well spill-over to mobility in the labour market. On the other hand to maintain their rent control benefits unemployed individuals are presumably less demanding when accepting a job in the local labour market. Based on a rich Danish data set we investigate the empirical contents of the issue, and find results that are in clear accordance with the theoretical predictions.

JEL Classification: $\quad$ C41, J61, J64, D45, L51

Keywords: rent control, unemployment duration, search model

Corresponding author:

Michael Svarer

Department of Economics

University of Aarhus

Building 320

8000 Aarhus C

Denmark

Tel.: +4589421598

Fax: +4586136334

Email: michael@svarer.dk

\footnotetext{
* Financial support from the Danish Social Science Research Council is gratefully acknowledged. Michael Svarer thanks the Danish National Research Foundation for support through its grant to CAM. We are grateful to seminar participants at Southern University of Denmark and University of Aarhus for helpful comments. The views expressed are not necessarily reflecting those of the Danish Economic Council.
} 


\section{Introduction}

Rent controls have been a permanent feature of the Danish private rental market for more than 60 years. Recently, Munch \& Svarer (2002) show that for a typical household in the Danish private rental sector, tenancy duration is more than six years longer if the apartment belongs to the 10 per cent most regulated units than if it belongs to the 10 per cent least regulated units. The purpose of the present paper is to investigate whether the reduced mobility in the housing market carries over to the labour market. The proposed mechanism is that since rent control increases costs of moving, unemployed workers enjoying rent control benefits tend to search less for jobs outside their local labour market. In addition, they are also less likely to accept job offers from employers located outside their local labour market. This story is not new and at least since Hayek's description of the repercussions of rent regulation in the labour market in Vienna in 1929 (Frasier Institute, 1975) there has been some focus on the potential negative impacts of rent control on labour mobility. However, as far as the authors of this article are aware, there have been made no attempts to empirically establish the importance of rent control on labour market dynamics. This paper is a first step in that direction.

In order to investigate whether rent control affects the length of individual unemployment we first present a theoretical model. In the model unemployed workers can search for new jobs in two regions; their local labour market and a national labour market excluding 
the local labour market. We show that the prediction from the model is that transitions from unemployment to employment in the national labour market is indeed hampered by the presence of rent control. On the other hand, the transition from unemployment to a new job in the local labour market is reinforced by rent control.

Our empirical analysis is based on a rich register-based data set collected by Statistics Denmark. It covers 10 per cent of the adult population and contains information on labour market status, housing status and various personal characteristics in the period from 1997 to 2000 . Of particular relevance is that the data set allows us to construct a measure of the extent to which each housing unit is rent controlled. The rent control benefit for a housing unit is calculated as the difference between a predicted uncontrolled rent and the actual rent paid.

We find that individuals occupying housing units with relatively high rent control benefits experience longer unemployment spells compared to their less fort unate counterparts, when the transition to a job in the national labour market is considered. In contrast, the opposite is true when transitions to a job in the local labour market is considered. Our findings are therefore in complete accordance with the theoretical predictions.

This study contributes to the growing literature on the effects of rent control. Among economists there seems to be consensus on the misfortunes of rent control when it comes to the effects on quantity and quality of housing (Alston et al., 1992). In addition, the opponents of rent control argue that regulations imply serious inefficiencies in the housing market. These inefficiencies range from lack of maintenance due to low economic profits for landlords (Gyourko and Linneman, 1990) over misallocation of housing (Glaeser and 
Luttmer, 2003) to reduced mobility in the housing market (Munch \& Svarer, 2002). On the other hand, less critical commentators on rent control argue that the regulations provide tenants with security and therefore improve welfare for a large group of usually socioeconomic weak citizens in the housing market (Arnott, 2003). It has also been argued that the presence of (mild) rent control can be welfare improving since landlords have monopsony power and therefore tend to set rents above marginal cost levels. Hence, a mild rent control can distribute some of the economic rent from landlords to tenants (Arnott and Igarashi, 2000).

In sum, the net effect of rent control on efficiency and equity in the housing market is an open question and as Arnott (2003) states ".. since economically sound arguments can be made on both sides of almost any public policy debate, decisions should be based on a quantitative assessment of the proposed policy's costs and benefits.". This paper is a step in that direction, since we measure the impact of rent control on the functioning of the labour market.

The paper is organized as follows. In Section 2 we present a basic theoretical model. Section 3 shortly discusses the main features of the Danish private rental housing market. The characteristics of rent control in Denmark fit well with the description of rental housing markets of several other countries. Hence, the results presented here also have implication for other countries. The data set is described in Section 4 along with a description of the calculation of rent control benefits. Section 5 contains a description of the econometric specification. In Section 6 we present the results, and in Section 7 we conclude. 


\section{Model}

This section sets up a search model with two labour markets, a local labour market labelled $A$, and a national labour market, excluding the local market, which we denote by $B$. We assume that workers can not live and work in different regions. Let the offer arrival rate for job offers be $\lambda_{A}$ and $\lambda_{B}$ in the two regions, respectively, and let the wage offer distribution be $F(w)$. This distribution is assumed identical across regions. Unemployment benefit, which is received as long as unemployed, is denoted by $b$ and when living in rent controlled housing the rent control benefit is $r$. The discount rate is $\rho$.

To proceed we first consider an economy without rent control. Jobs are assumed to last forever, implying that the asset value of employment is

$$
V^{E}(w)=w / \rho
$$

The expected discounted lifetime income for an unemployed, $V^{U}$, can be expressed as the solution to the asset pricing equation

$$
\rho V^{U}=b+\left(\lambda_{A}+\lambda_{B}\right) \int \max \left(V^{E}(w)-V^{U}, 0\right) d F(w)
$$

where the opportunity cost of searching while unemployed is equal to income while unemployed plus the expected capital gain attributable to searching for an acceptable job where acceptance occurs only if the value of employment, $V^{E}(w)$, exceeds that of continued search. Note, since the value of employment increases in the wage, $w$, and the value of unemployment does not, there exists a reservation wage, $w^{*}$, for which wages above $w^{*}$ make employment more favorable than continued search. The reservation wage can be 
expressed as

$$
w^{*}=b+\frac{\lambda_{A}+\lambda_{B}}{\rho} \int_{w^{*}}^{\bar{w}}\left(w-w^{*}\right) d F(w) .
$$

Hence, in this simple setup, the reservation wage is the same for accepting a job offer in the two labour markets.

Now, for a worker in regulated rental housing, the situation is slightly different. First of all, the value of accepting a job now depends on the location of the job. We make the assumption that moving implies a loss of the benefit associated with rent regulation ${ }^{1}$. Hence, the value of employment locally is

$$
V^{E R}(w)=\frac{w+r}{\rho}
$$

while the value of accepting a job in region $B$ is $V^{E}(w)$.

The asset value of unemployment for an individual in rent regulated housing is

$$
\begin{aligned}
\rho V^{U R} & =b+r+\lambda_{A} E \max \left(V^{E R}(w)-V^{U R}, 0\right)+\lambda_{B} E \max \left(V^{E}(w)-V^{U R}, 0\right) \\
& =b+r+\frac{\lambda_{A}}{\rho} \int_{\rho V^{U R_{-r}}}^{\bar{w}}\left(w-\left(\rho V^{U R}-r\right)\right) d F(w)+\frac{\lambda_{B}}{\rho} \int_{\rho V^{U R}}^{\bar{w}}\left(w-\rho V^{U R}\right) d F(w) .
\end{aligned}
$$

As it can be seen from this equation, this leads to a dual reservation wage strategy; for the local labour market, the reservation wage is $w_{R A}^{*} \equiv \rho V^{U R}-r$, while for the national labour

\footnotetext{
${ }^{1}$ Clearly, the probability of obtaining a rent controlled housing unit in the new region is presumably not zero. However, as rent controlled housing units are characterized by excess demand they are hard to obtain. We therefore make the rather pausible assumption that the rent control benefit is lost if the housing unit is vacated. An alternative presentation of this model is that the rent control benefit is simply a moving cost facing all individuals who decide to move. The qualitative results derived below still hold in that case.
} 
market, it equals $w_{R B}^{*} \equiv \rho V^{U R}$. Trivially, we have $w_{R A}^{*}<w_{R B}^{*}$. Thus the unemployed person is willing to accept a job paying a lower wage if that implies staying in the regulated apartment, while moving implies giving up the rent regulated apartment, and hence the reservation wage is higher, because it must compensate the unemployed worker for the lost subsidy.

To see how rent control affects the behavior of unemployed workers we compare their reservation wages in a system with rent control and a system without, that is we want to determine the size of $w^{*}$ relative to $w_{R A}^{*}$ and $w_{R B}^{*}$. Rewriting the expression for the value function associated with being unemployed while living in rent regulated housing, we obtain

$$
w_{R B}^{*}=b+r+\frac{\lambda_{A}}{\rho} \int_{w_{R A}^{*}}^{\bar{w}}\left(w-\left(w_{R B}^{*}-r\right)\right) d F(w)+\frac{\lambda_{B}}{\rho} \int_{w_{R B}^{*}}^{\bar{w}}\left(w-w_{R B}^{*}\right) d F(w) .
$$

Consider the sign of $w^{*}-w_{R B}^{*}$.

$$
\begin{aligned}
w^{*}-w_{R B}^{*}= & \frac{\lambda_{A}+\lambda_{B}}{\rho}\left(\int_{w^{*}}^{\bar{w}}\left(w-w^{*}\right) d F(w)-\int_{w_{R B}^{*}}^{\bar{w}}\left(w-w_{R B}^{*}\right) d F(w)\right) \\
& -r-\frac{\lambda_{A}}{\rho}\left(\int_{w_{R A}^{*}}^{w_{R B}^{*}}\left(w-w_{R A}^{*}\right) d F(w)+r \int_{w_{R B}^{*}}^{\bar{w}} d F(w)\right) .
\end{aligned}
$$

Now assume $w^{*} \geq w_{R B}^{*}$. The first element in the sum is negative; the option value of search is declining in the reservation wage. In addition the remaining terms are always negative. Therefore, by contradiction, we must have $w^{*}<w_{R B}^{*}$.

After rearranging terms, we can write $w_{R A}^{*}$ in the following way:

$$
w_{R A}^{*}=b+\frac{\lambda_{A}}{\rho} \int_{w_{R A}^{*}}^{\bar{w}}\left(w-w_{R A}^{*}\right) d F(w)+\frac{\lambda_{B}}{\rho} \int_{w_{R B}^{*}}^{\bar{w}}\left(w-\left(w_{R A}^{*}+r\right) d F(w) .\right.
$$

Let us look at $w^{*}-w_{R A}^{*}$. 


$$
\begin{aligned}
w^{*}-w_{R A}^{*}= & \frac{\lambda_{A}+\lambda_{B}}{\rho}\left(\int_{w^{*}}^{\bar{w}}\left(w-w^{*}\right) d F(w)-\int_{w_{R A}^{*}}^{\bar{w}}\left(w-w_{R A}^{*}\right) d F(w)\right) \\
& +\frac{\lambda_{B}}{\rho}\left(\int_{w_{R A}^{*}}^{w_{R B}^{*}}\left(w-w_{R A}^{*}\right) d F(w)+r \int_{w_{R B}^{*}}^{\bar{w}} d F(w)\right) .
\end{aligned}
$$

Assume that $w^{*} \leq w_{R A}^{*}$. Now, the first component in this sum is positive, since the reservation wage is inversely related to the option value of search. The remaining components are obviously positive too, which leads to a contradiction.

\section{Proposition $1 w_{R A}^{*}<w^{*}<w_{R B}^{*}$}

To envision how the different reservation wages affect individual transitions from unemployment we state the hazard rate out of unemployment to a job in region $A$ and $B$ respectively in a system without rent control (and moving costs), as

$$
\theta_{A}=\lambda_{A}\left(1-F\left(w^{*}\right)\right) \quad \text { and } \quad \theta_{B}=\lambda_{B}\left(1-F\left(w^{*}\right)\right)
$$

The exit rate from unemployment is the product of the arrival rate of job offers and the probability that the offer is accepted. In a system with rent control the relevant hazard rates for exit to a new job in the local labour market and the national labour market, respectively, are

$$
\theta_{R A}=\lambda_{A}\left(1-F\left(w_{R A}^{*}\right)\right) \quad \text { and } \quad \theta_{R B}=\lambda_{B}\left(1-F\left(w_{R B}^{*}\right)\right)
$$

its easy to see that $\theta_{R B}<\theta_{B}$ and $\theta_{A}<\theta_{R A}$, so individuals in rent controlled housing have higher transition rates into employment in the local labour market, while they have lower transition rates into jobs in other regions. 
What, then, is the relation between the overall hazard rates, that is

$$
\theta_{A}+\theta_{B} \gtreqless \theta_{R A}+\theta_{R B} ?
$$

To answer this question, look at the following:

$$
\begin{aligned}
\theta_{A}+\theta_{B}-\left(\theta_{R A}+\theta_{R B}\right)= & \lambda_{A}\left(1-F\left(w^{*}\right)\right)+\lambda_{B}\left(1-F\left(w^{*}\right)\right) \\
& -\lambda_{A}\left(1-F\left(w_{R A}^{*}\right)\right)-\lambda_{B}\left(1-F\left(w_{R B}^{*}\right)\right) \\
= & \lambda_{A}\left[F\left(w_{R A}^{*}\right)-F\left(w^{*}\right)\right]+\lambda_{B}\left[F\left(w_{R B}^{*}\right)-F\left(w^{*}\right)\right]
\end{aligned}
$$

The first component is negative, and the second positive, hence the answer to the question posed depends on the relative size of $\lambda_{A}$ and $\lambda_{B}$, and the relative sizes of $F\left(w_{R A}^{*}\right)-F\left(w^{*}\right)$, and $F\left(w_{R B}^{*}\right)-F\left(w^{*}\right)$, and is, without additional assumptions, an empirical question.

To sum up, the job search model presented in this section demonstrates that the impact of rent control on unemployment duration is an empirical question. Clearly, geographic mobility of unemployed workers is reduced by the presence of rent control, since unemployed workers would need to be compensated for the lost rent control benefit. Therefore, they set higher reservation wages (or search less actively) outside the local labour market. This prolongs unemployment duration. On the other hand, in order to maintain their rent control benefit, unemployed individuals set lower reservation wages in the local labour market, which works in the opposite direction, i.e., it reduces unemployment duration. The overall effect on unemployment duration is ambiguous.

Of course, if we look beyond unemployment duration, one realizes that there may be other effects of rent control on the labour market. First, the willingness to commute, and 
hence commuting distance, should be larger for unemployed workers in rent controlled housing units. Second, in terms of matching models, by setting a lower reservation wage for local jobs, unemployed workers accept matches with lower productivity (lower wages). This implies an efficiency loss for the economy as a whole. Moreover, it implies that employed individuals in rent controlled housing units will conduct more on-the-job search, ceteris paribus, because they have more to gain from this. However, it is beyond the scope of this paper to analyze these effects in depth.

\section{The Danish private rental housing market}

There are around 2.5 mill. housing units in the Danish housing market, and it comprises four main sectors, each characterized by a different set of legal regulations. The four sectors are owner occupied housing (51\%), co-operative housing (6\%), where the occupants own a part of the cooperative and have the right to use a specific apartment, public rental housing (19\%), which is rented housing provided by housing associations, and private rental housing $(18 \%)$. Here we only consider the market for private rental housing.

Rent controls have been a permanent feature of the private rental market for more than 60 years. Rents in most private rented dwellings in larger urban areas are cost-based, regulated rents. Landlords are allowed to pass on all costs (property taxes included) actually incurred in the day-to-day operation of the property and a prescribed charge to cover maintenance cost. The cost-based rent also allows for a capital charge, which can vary between 7 and 14 per cent depending on the age of the dwelling. However, 
the capital charge is calculated on the basis of the value of the property in 1973 and no allowance for inflation on this part of the rent is permitted. Also, landlords cannot raise rents due to increased demand for housing. Thus the capital payoff is eroded by inflation and depreciation. Rents in all dwellings constructed after 1991 are exempted from rent control, but only a small number of private rented dwellings (about $6 \%$ ) has been built since 1991.

In minor rural districts the local authorities are not imposing rent control in the traditional sense. Instead rents are determined by legislation at the "value of the rental unit", which is not a market rent. The "value of the rental unit" is determined by comparing with similar housing units in the area, and so it is a rather vague concept. However, also housing units in urban areas can be rented at the "value of the rental unit" if they are thoroughly improved when they become vacant. In this way substantial rent increases are allowed for, and landlords sometimes use this route to escape rent control.

Another feature of the private rented sector is that whenever a private rented property is for sale, legislation gives current residents the right to take over the property at the offered price and convert it to a co-operative. The offered price typically reflects controlled rents, so most properties are taken over by residents under favorable conditions. As a result the total number of private rented dwellings has been in decline.

Recently, Lind (2001) has surveyed existing rent regulating systems in a number of European countries and North American cities. The main message is that rent regulation exists in many countries (e.g. Austria, Germany, Sweden, certain states in the US, provinces in Canada and others), and that traditional rent control that keeps rents below 
market rents are in decline but still widespread. So even though the present analysis is based on data from the Danish housing market, its implications are valid in a much wider context.

\section{Data}

To investigate the effect of rent control on the duration of unemployment spells a very rich data set, which is drawn from administrative registers made available by Statistics Denmark, is employed. The complete data set consists of a $10 \%$ random sample of the Danish adult population, and it comprises information on a large number of demographic and socioeconomic variables as well as information about physical characteristics of all housing units occupied by the sample population in the years 1997-2000 and information about individuals labour market status. Of particular interest are the dependent variable, the length of unemployment spells, and the measure of the benefit associated with occupying a rent controlled housing unit. These variables are described in more detail below.

\subsection{Unemployment spells and geographical mobility}

For all individuals in the original sample weekly event histories for the states in the labour market have been constructed. Here we are interested in the states unemployment and employment, but other states, such as education, different leave schemes, and early retirement, are also known. The sample has been restricted to the inflow to unemploy- 
ment during the years 1997-2000, that is, we construct a flow sample of unemployment spells. The duration of each unemployment spell is known in weeks, and if the subsequent destination state is employment then this is known as well.

To distinguish between workers finding jobs by being geographically mobile and workers finding jobs in the local labour market, local labour markets must be defined. A local labour market consists of municipalities between which the internal migration rate is 50 $\%$ higher than the external migration rate, cf. Andersen (2000). There are 51 such commuting areas in Denmark. An unemployed worker is then defined to be geographically mobile if he or she gets a job and moves to another commuting area up to 8 weeks before and 52 weeks after the beginning of the job spell. This definition is based on the fact that the majority of all moves take place within this interval reflecting that workers typically first accept a new job and then search for a permanent new residence. Gregg et al. (2003) find a similar pattern for the UK.

There are 14,645 persons in the sample, contributing a total of 31,966 unemployment spells. Out of these, approximately $40 \%$ are temporary layoffs, that is, the unemployed worker returns to the previous employer at the end of the unemployment spell. In this study, temporary layoffs are considered to be right censored, since we are mainly interested in 'traditional' unemployment spells, where workers genuinely lose their jobs. 10,117 of these unemployment spells then end by the individual finding a new job in the local labour market, while only 610 workers find new jobs outside their commuting area. The remainder of the unemployment spells are either temporary layoffs, right-censored, or they end with a transition into another state (outside the labour market). 


\subsection{The rent control benefit}

Moving dates are known for all individuals in the sample such that unemployment spells can be divided into housing unit specific parts. For each part we then need a measure for the extent to which the unit is rent regulated, which is to be included in the duration analysis as a time varying regressor.

The measure for a workers annual benefit from rent control is taken from Munch \& Svarer (2002). That is, the rent control benefit for a housing unit is the difference between the uncontrolled rent predicted for that unit and the actual rent paid on that unit. The predicted uncontrolled rent is derived by use of the Danish Tax Authorities (henceforth DTA) 1999 model for owner occupied housing. The DTA model is a hedonic price function for prices on the free market for owner occupied dwellings, and it is based on actual sales in the years 1996-1999 and a long list of housing traits for each unit (e.g. square meters, number of rooms, construction year, year for major improvements, floor, number of apartments in property, the presence of kitchen, shower, and toilet). In particular there is a high degree of geographical precision as each housing unit has been placed into one of more than 50,000 different areas with their own geographical coefficient. The original purpose of the model is to determine the value of the owner occupied housing units for tax reasons.

The DTA model is applied to all rented housing units to obtain the estimated uncontrolled price. The uncontrolled rent is then derived by multiplying with an estimate of user costs in Denmark. To arrive at the rent control benefit the actual rent paid is 
subtracted, but this variable is only available for about $50 \%$ of the rented units in the data. Therefore the missing rents are estimated by the Heckman two step procedure to control for sample selection. ${ }^{2}$

In the econometric model below we use a relative measure of the rent control benefit as an explanatory variable. That is, we divide all housing units into deciles according to their rent control degree, where the rent control degree is the rent control benefit divided by the uncontrolled rent. This is done for three reasons. First, the estimated user cost level is somewhat arbitrary, but the level of user costs does not affect the relative rent control degree. Second, the price level of owner occupied housing could be affected by spill overs from rent control in the market for rented housing (see e.g. Hackner \& Nyberg, 2000 for a theoretical argument). Again the relative rent control degree of a housing unit is independent of the level of the predicted uncontrolled price. Third, the method to measure rent control benefits is likely to produce measurement errors, since the hedonic rent function used to predict uncontrolled rents is unlikely to fully explain rents. The impact of potential measurement error is reduced by using deciles of the rent control degree. These issues are discussed in more detail in Munch \& Svarer (2002).

Finally it should be noted that the available DTA model is for 1999 and in addition rents are only observed for 1999, but a relative measure of the degree to which each housing unit is regulated within each of the years 1997-2000 is required. This is solved by allocating a 1999 relative rent control degree to units in other years in the following way. First, the rent control degrees for the stock of rented units in 1999 is calculated and these

\footnotetext{
${ }^{2}$ For more details on this see Munch \& Svarer (2002).
} 
are divided into deciles. From this 1999 distribution the decile limits are retained. Next, using the 1999 DTA model and 1999 rents, the 1999 rent control degree is calculated for all units in 1997, 1998 and $2000^{3}$ and in each year the units are divided into deciles according to the 1999 decile limits.

\subsection{Explanatory variables}

In the subsequent empirical model we also include various other explanatory variables. Specifically, we have information on the individual's age, level of education, civil status (married/cohabiting), UI fund membership, wealth, and finally their replacement rate. The latter is the ratio of the UI benefits they receive to the most recent wage. The means and standard deviations of the explanatory variables are presented in Table 1.

\section{$5 \quad$ Empirical model}

In this section we describe the econometric model used to investigate how rent control affects individual transitions out of unemployment. We are interested in modelling the transition out of unemployment and into employment either in the local labour market or in the national labour market. The empirical counterparts to the transition rates defined in Section 2 are the reduced-form hazard rates.

Let the continuous stochastic variable $T, T \in(0, \infty)$, denote unemployment duration.

\footnotetext{
${ }^{3}$ The 1999 rent control degree can change over time if some of the physical characteristics of a unit have changed which is known in the data set.
} 
The hazard rate, which denotes the probability for an individual with observed characteristics $x$ and unobserved characteristics $v$ of finding a job in the interval $t+d t$ given that the individual is still unemployed at time $t$, is then given by

$$
h(t \mid x, v)=\lim _{d t \rightarrow \mathbf{0}} \frac{\mathbf{P}(t<T \leq t+d t \mid T>t, x, v)}{d t} .
$$

The hazard function is specified as a mixed proportional hazard model. That is, the hazard is the product of the baseline hazard, which captures the time dependence and a function of observed and unobserved characteristics

$$
h(t \mid x, v)=\lambda(t) \cdot \varphi(x, v)
$$

where $\lambda(t)$ is the baseline hazard and $\varphi(x)$ is the scaling function specified as $\exp (x \beta+v)$.

Since we argued in section 2 that the effect of rent control on the hazard rate out of unemployment depends on whether the new job is local or not we specify a competing risks model with two destinations: $a$ being employment in a new job in the local labour market and $b$ being employment at a new employer in another region ${ }^{4}$. Let $d_{a}=\mathbb{I}_{\{j=a\}}$ and $d_{b}=\mathbb{I}_{\{j=b\}}$ denote the two destination state indicators for the events in the brackets. Each cause-specific hazard rate is specified as a mixed proportional hazard function with a piecewise constant baseline hazard with splitting times $\tau_{0}=0, \tau_{1}, \ldots, \tau_{K}=+\infty$. The value of the baseline hazard in the $k^{\prime}$ th interval is given by $\lambda_{i}^{k}$. Let $k(t): \Re_{+} \curvearrowright\{1,2, \ldots, K-1, K\}$ be a function that maps the duration, $t$, into interval $k$. Notice that the baseline hazard can attain arbitrary flexibility by increasing the number of intervals. The individual

\footnotetext{
${ }^{4}$ All other destinations are treated as right censored.
} 
contribution to the likelihood function is given by

$$
\begin{aligned}
\mathcal{L}(\theta, \beta, \gamma, v)= & \prod_{j=\{a, b\}}\left(\lambda_{j}^{k(t)} \cdot \exp \left[\beta_{j} x+\gamma_{j} R C+v_{j}\right]\right)^{d_{j}} \\
& \times \exp \left(\begin{array}{c}
-\sum_{j=\{a, b\}} \exp \left[\beta_{j} x+\gamma_{j} R C+v_{j}\right] . \\
\left(\sum_{h=1}^{k(t)-1} \lambda_{j}^{h}\left(\tau_{h}-\tau_{h-1}\right)+\lambda_{j}^{k(t)}\left(t-\tau_{k(t)-1}\right)\right)
\end{array}\right) .
\end{aligned}
$$

where $R C$ denotes the rent control decile. To obtain the parameter estimates we apply maximum likelihood estimation on the marginal likelihood function ${ }^{5}$

$$
\mathcal{L}(\lambda, \beta, \gamma)=\iint \mathcal{L}(\lambda, \beta, \gamma, v) d G\left(v_{a}, v_{b}\right)
$$

The unobserved heterogeneity distribution follows a bivariate discrete distribution with $2 \times 2$ points of support. We normalize one of the support points in each of the cause-specific hazard functions to zero, since the baseline hazard acts as a constant term.

\section{Results}

In this section we present the results. Table 1 contains the results from the competing risks duration model. The parameter estimates describe the effect of the explanatory variables on the escape rate from unemployment. A positive sign implies that the specific characteristic increases the escape rate from unemployment or put differently reduces the expected duration of the unemployment spell. We will focus our discussion on the effect of rent control and simply note that the effects of the other explanatory variables are in accordance with other studies of individual unemployment duration and will not be discussed here.

\footnotetext{
${ }^{5}$ For more details on the likelihood function see e.g Jensen \& Svarer (2003).
} 
TABLE 1: EFFECTS ON UNEMPLOYMENT HAZARD ${ }^{6}$

\begin{tabular}{|c|c|c|c|c|c|c|}
\hline & \multicolumn{2}{|c|}{ New job, national } & \multicolumn{2}{|c|}{ New job, local } & \multicolumn{2}{|c|}{ Descriptives } \\
\hline & Coeff. & Std. dev. & Coeff. & Std. dev. & Mean & Std. dev. \\
\hline Rent control degree $(/ 10)$ & -0.5187 & 0.1786 & 0.1177 & 0.0446 & 0.42 & 0.28 \\
\hline Female & -0.2736 & 0.1071 & -0.0459 & 0.0261 & 0.49 & \\
\hline Children in household & -0.5460 & 0.1441 & -0.1630 & 0.0316 & 0.25 & \\
\hline Age, $25-29$ & -0.2034 & 0.1255 & -0.0128 & 0.0363 & 0.28 & \\
\hline Age, 30-39 & -0.8731 & 0.1444 & -0.2869 & 0.0375 & 0.25 & \\
\hline Age, $40-49$ & -1.8556 & 0.2160 & -0.5020 & 0.0416 & 0.14 & \\
\hline Age, $50+$ & -2.7625 & 0.3276 & -0.7976 & 0.0460 & 0.11 & \\
\hline Married/cohabiting & 0.2745 & 0.1058 & 0.0798 & 0.0249 & 0.43 & \\
\hline Large city & 1.8557 & 0.2133 & 0.0328 & 0.0360 & 0.21 & \\
\hline Rural area & 1.8030 & 0.2123 & 0.0220 & 0.0335 & 0.61 & \\
\hline Basic edu. & -1.0747 & 0.1809 & -0.3748 & 0.0393 & 0.35 & \\
\hline High school & 0.1650 & 0.1731 & 0.0051 & 0.0442 & 0.12 & \\
\hline Skilled & -0.6069 & 0.1696 & -0.1026 & 0.0387 & 0.34 & \\
\hline Not member of UI fund & -0.0332 & 0.1143 & -0.4145 & 0.0277 & 0.19 & \\
\hline Building & -0.5503 & 0.3020 & 0.5271 & 0.0597 & 0.04 & \\
\hline Metal & -0.0055 & 0.2357 & 0.1179 & 0.0690 & 0.04 & \\
\hline Manufacturing & -0.5151 & 0.1642 & 0.0141 & 0.0326 & 0.18 & \\
\hline Female unskilled & -0.7573 & 0.4241 & -0.0958 & 0.0732 & 0.04 & \\
\hline Academics & 0.2048 & 0.2214 & -0.0614 & 0.0575 & 0.06 & \\
\hline Wealth $(/ 1000000)$ & -0.0513 & 0.2786 & -0.0603 & 0.0684 & -0.02 & 0.19 \\
\hline UI replacement rate & -0.6173 & 0.3531 & -0.4799 & 0.0742 & 0.79 & 0.16 \\
\hline Number of individuals & & & & & &, 645 \\
\hline
\end{tabular}

Note: Bold figures indicate a significant coefficient at the 5\% level.

The novel finding in Table 1 is the effect of rent control. In line with the theoretical predictions in Section 2 unemployed individuals in private rental housing, who are occupying a housing unit that give rise to a high rent control degree, are less likely to leave unemployment for a job outside their local labour market. In contrast they are relatively more inclined to find a job in their local labour market. The direct effect of rent control on the functioning of the labour market is therefore not unambiguously negative, as far as unemployment duration is concerned. If the goal is to bring individuals into employment as quickly as possible rent control does not jeopardize the objective. We also tried to estimate a single risk version of the model. In that model there was no significant (at the $5 \%$ level) association between the rent control degree and the escape rate from

\footnotetext{
${ }^{6}$ The estimated baseline hazard and components of the unobserved heterogeneity components are not presented in the table. The cause-specific hazard functions are depicted in Figure 1. The reference categories are age 18-24, single, living in Copenhagen, high level of education, and member of a UI fund.
} 
unemployment. The results are available from the authors upon request.

That individuals are inclined to stay in their local labour market, even though they are living in rental housing, is shown in Figure 1. Here the two cause-specific baseline functions are drawn. The hazard rate into a new job in the local job market is markedly higher than the national labour market counterpart, reflecting that very few of the unemployed are moving to obtain employment. This phenomenon, however, is not a direct consequence of rent control. As shown by Munch \& Svarer (2002) households living in highly rent controlled housing units are much less inclined to move, but as this baseline hazard shows, mobility is low irrespective of whether or not one lives in a controlled housing unit.

Thus, we must look for other potential explanations for the low level of geographical mobility among unemployed workers. In Denmark and in many other European countries, regional mobility is very low due to e.g. easy access to early retirement schemes and disability pensions. In a comparison between Europe and the US, Decressin \& Fatás (1995) find that in Europe region-specific shocks are absorbed by adjustments in the participation rate, while in the US workers move. Also, relatively generous unemployment benefits are typically available in Europe, and the results of Table 1 suggest that the replacement rate of UI benefits have a stronger negative effect on the mobility hazard than on the local job hazard. Hence rent control is probably most harmful in countries where regional mobility constitutes an important tool of adjustment to shocks in the labour market (such as the US). 


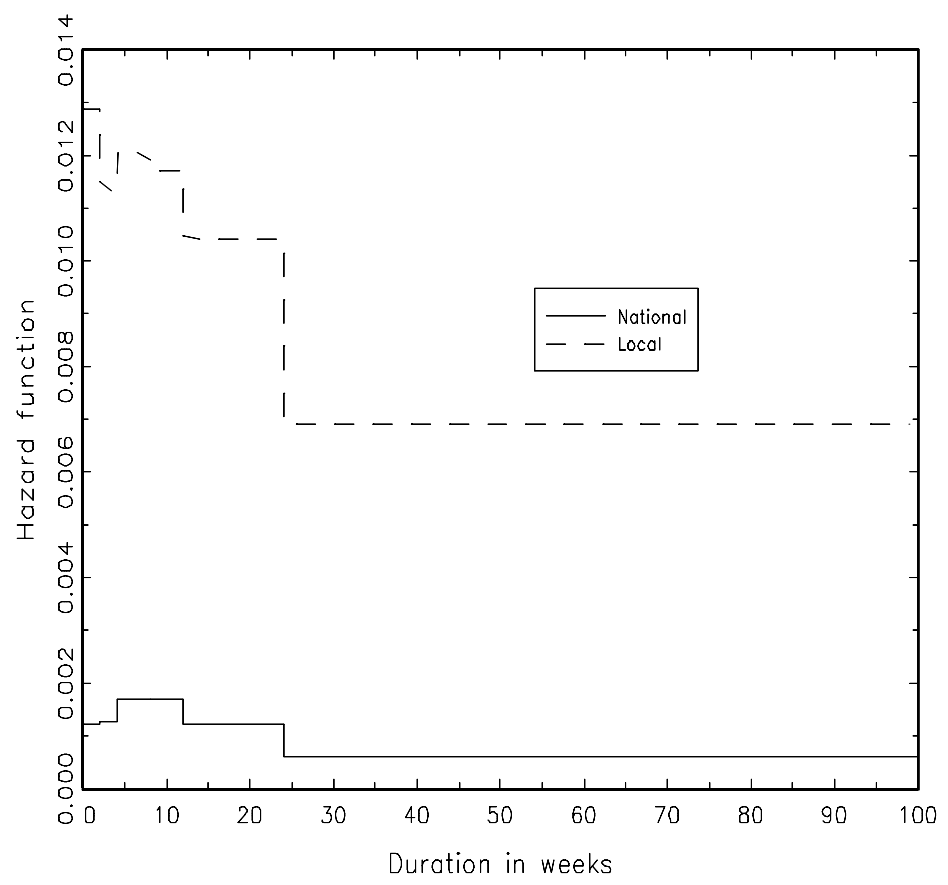

Figure 1: Cause-specific hazard functions.

\section{Discussion and Conclusion}

In this paper we have investigated the effect of rent control on individual unemployment durations. We have established that the expected effect arising from rent control is that individuals occupying more rent controlled housing units are less likely to accept jobs outside their local labour market, whereas they are more likely to accept job offers in their local labour market, i.e. to accept jobs that do not require a change of residence. Our empirical results confirm the theoretical predictions. 
As discussed in the theoretical section, prolonged unemployment duration is not the only potential distortionary impact on the labour market generated by rent control. Another potential effect is that unemployed workers living in housing with a large degree of rent control should be willing to accept jobs that involve longer commuting distances. Having access to commuting distances (knowing the location of the job and the house or apartment), we were, however, unable to find any significant association between commuting distance and rent control (results from OLS estimations are available upon request).

An efficient labour market would match workers to jobs where their productivity is the highest. Rent control provides workers with incentives to accept less than optimal matches, but it is not clear how to measure this phenomenon empirically. One possibility would be to perform wage regressions of the accepted wage, including rent control as a regressor, but unfortunately, the wage in our sample is an average hourly wage over the whole year, and this may in some cases reflect wages in previous or subsequent jobs, that is, not the job immediately following the unemployment spell.

One interesting implication of our results in combination with the potential matching inefficiency effect discussed above is that they give some support to a proposed mechanism through which rent control has harmful effects. Hardman \& Ioaniddes (1999) establish in a theoretical growth model that rent control can adversely affect economic growth. Their argument goes as follows. Since rent control makes workers less inclined to be geographically mobile, firms face a harder time hiring the right man for the job. This in turn make labour a more expensive input factor, and as a reaction firms substitute to capital. This increases the demand for capital which increases the price of capital - the 
interest rate. The higher interest rate will reduce investments and hence economic growth. The results in this paper indeed suggest that the first part of their line of reasoning finds some empirical support. We have, however, been unable to test the remainder of the argument, which will be left for future research.

\section{References}

[1] R.M. Alston, J. Kearl and M.B. Vaughan, Is there consensus among economists in the 1990's?, American Economic Review, 82, 203-209 (1992).

[2] A.K. Andersen, Commuting areas in Denmark, AKF, Copenhagen (2000).

[3] R. Arnott and M. Igarashi, Rent control, mismatch costs and search efficiency, Regional Science and Urban Economics, 30, 249-288 (2000).

[4] R. Arnott, Tenancy rent control, Forthcoming Swedish Economic Policy Review $(2003)$.

[5] Danish Economic Council, "Danish Economy", Copenhagen, (spring 2001).

[6] J. Decressin \& A. Fatás, Regional labor market dynamics in Europe, European Economic Review, 39,1627-1655 (1995).

[7] E.L. Glaeser and E.F. Luttmer, The misallocation of housing under rent control, Forthcoming American Economic Review (2003). 
[8] P. Gregg, S. Machin and A. Manning, Mobility and joblessness, in: Seeking a premier league economy, ed. R. Blundell, D. Card \& R.B. Freeman, The University of Chicago Press (2003).

[9] J. Gyourko and P. Linneman, Rent control and rental housing quality: A note on the effects of New York City's old controls, Journal of Urban Economics, 27, 398-409 (1990)

[10] F. A. Hayek, Austria: The repercussions of rent restrictions, in: Rent control: a popular paradox, Frasier Institute (1975).

[11] J. Häckner and S. Nyberg, Rent control and prices of owner occupied housing, Scandinavian Journal of Economics, 102, 311-324 (2000).

[12] A.M. Hardman and Y.M. Ioannides, Residental mobility and the housing market in a two-sector neoclassical growth model, Scandinavian Journal of Economics, 101, $315-335$ (1999).

[13] P. Jensen and M. Svarer, Short- and long-term unemployment: Do temporary layoffs affect this distinction?, Empirical Economics, 28, 1, 23-44 (2003).

[14] T. Lancaster, "The econometric analysis of transition data", Cambridge University Press, Cambridge (1990).

[15] H. Lind, Rent regulation: A conceptual and comparative analysis, European Journal of Housing Policy, 1, 41-57 (2001). 
[16] J. Munch and M. Svarer, Rent control and tenancy duration, Journal of Urban Economics, 52,3, 542-560 (2002). 


\section{IZA Discussion Papers}

\begin{tabular}{|c|c|c|c|c|}
\hline No. & Author(s) & Title & Area & Date \\
\hline 828 & $\begin{array}{l}\text { D. Checchi } \\
\text { T. Jappelli }\end{array}$ & School Choice and Quality & 3 & $07 / 03$ \\
\hline 829 & $\begin{array}{l}\text { J. J. Heckman } \\
\text { X. Li }\end{array}$ & $\begin{array}{l}\text { Selection Bias, Comparative Advantage and } \\
\text { Heterogeneous Returns to Education: Evidence } \\
\text { from China in } 2000\end{array}$ & 6 & $07 / 03$ \\
\hline 830 & T. J. Hatton & $\begin{array}{l}\text { Emigration from the UK, } 1870-1913 \text { and } 1950- \\
1998\end{array}$ & 1 & $07 / 03$ \\
\hline 831 & $\begin{array}{l}\text { J. H. Abbring } \\
\text { G. J. van den Berg }\end{array}$ & $\begin{array}{l}\text { Analyzing the Effect of Dynamically Assigned } \\
\text { Treatments Using Duration Models, Binary } \\
\text { Treatment Models, and Panel Data Models }\end{array}$ & 6 & 07/03 \\
\hline 832 & P.-C. Michaud & Joint Labour Supply Dynamics of Older Couples & 3 & $07 / 03$ \\
\hline 833 & H. Gersbach & $\begin{array}{l}\text { Structural Reforms and the Macroeconomy: The } \\
\text { Role of General Equilibrium Effects }\end{array}$ & 2 & $07 / 03$ \\
\hline 834 & $\begin{array}{l}\text { T. Boeri } \\
\text { J. I. Conde-Ruiz } \\
\text { V. Galasso }\end{array}$ & $\begin{array}{l}\text { Protecting Against Labour Market Risk: } \\
\text { Employment Protection or Unemployment } \\
\text { Benefits? }\end{array}$ & 3 & $07 / 03$ \\
\hline 835 & $\begin{array}{l}\text { G. Joseph } \\
\text { O. Pierrard } \\
\text { H. R. Sneessens }\end{array}$ & $\begin{array}{l}\text { Job Turnover, Unemployment and Labor Market } \\
\text { Institutions }\end{array}$ & 3 & $07 / 03$ \\
\hline 836 & M.-S. Yun & $\begin{array}{l}\text { A Simple Solution to the Identification Problem } \\
\text { in Detailed Wage Decompositions }\end{array}$ & 3 & $07 / 03$ \\
\hline 837 & W. Schnedler & $\begin{array}{l}\text { What You Always Wanted to Know About } \\
\text { Censoring But Never Dared to Ask - Parameter } \\
\text { Estimation for Censored Random Vectors }\end{array}$ & 6 & $07 / 03$ \\
\hline 838 & $\begin{array}{l}\text { S. Girma } \\
\text { H. Görg } \\
\text { E. Strobl }\end{array}$ & $\begin{array}{l}\text { Government Grants, Plant Survival and } \\
\text { Employment Growth: A Micro-Econometric } \\
\text { Analysis }\end{array}$ & 6 & $07 / 03$ \\
\hline 839 & $\begin{array}{l}\text { A. Bassanini } \\
\text { G. Brunello }\end{array}$ & $\begin{array}{l}\text { Is Training More Frequent When Wage } \\
\text { Compression is Higher? Evidence from the } \\
\text { European Community Household Panel }\end{array}$ & 6 & $08 / 03$ \\
\hline 840 & $\begin{array}{l}\text { E. Koskela } \\
\text { R. Stenbacka }\end{array}$ & $\begin{array}{l}\text { Equilibrium Unemployment Under Negotiated } \\
\text { Profit Sharing }\end{array}$ & 1 & $08 / 03$ \\
\hline 841 & $\begin{array}{l}\text { B. H. Baltagi } \\
\text { D. P. Rich }\end{array}$ & $\begin{array}{l}\text { Skill-Biased Technical Change in U.S. } \\
\text { Manufacturing: A General Index Approach }\end{array}$ & 1 & 08/03 \\
\hline 842 & $\begin{array}{l}\text { M. Svarer } \\
\text { M. Rosholm } \\
\text { J. R. Munch }\end{array}$ & Rent Control and Unemployment Duration & 3 & 08/03 \\
\hline
\end{tabular}

An updated list of IZA Discussion Papers is available on the center's homepage www.iza.org. 